\title{
Potensi Imunomodulator Herbal Ekstrak Etanol Daun Pepaya Varietas Calina terhadap Struktur Jaringan Limpa Tikus Putih Galur Wistar
}

\author{
(ETHANOL EXTRACT OF CALINA PAPAYA LEAVES \\ AS A POTENTIAL HERBAL IMMUNOMODULATORS \\ ON THE SPLEEN TISSUE STRUCTURE OF WISTAR RATS)
}

\author{
Haris Setiawan ${ }^{1}$, Sri Wijayanti Wulandari ${ }^{2}$, Aritasya Nur Fitriyani ${ }^{1}$ \\ ${ }^{1}$ Laboratorium Struktur dan Fisiologi Hewan, \\ ${ }^{2}$ Laboratorium Bioteknologi, \\ Fakultas Sains dan Teknologi Terapan, Universitas Ahmad Dahlan, \\ Jl. Jend. A. Yani (Ringroad Selatan) Tamanan, \\ Banguntapan, Bantul, Daerah Istimewa Yogyakarta, Indonesia 55191 \\ Email: haris.setiawan@bio.uad.ac.id
}

\begin{abstract}
Calina papaya (Carica papaya L. Var. calina) is one of the many types of papaya that is widely cultivated in Indonesia. The leaf of this plant has flavonoid, polyphenol, tannin, and saponin as active compounds which are known to be an immunomodulator. This research aims to analyze ethanolic extract activity of papaya leaves as immunomodulator on the spleen histology of rats. Twenty four rats were divided into four groups, one control group $(0 \mathrm{mg} / \mathrm{kg} \mathrm{BW})$ and 3 treatment groups; each with doses as follow: $100 \mathrm{mg} / \mathrm{kg} \mathrm{BW}, 200 \mathrm{mg} / \mathrm{kg} \mathrm{BW}$, and $300 \mathrm{mg} / \mathrm{kg}$ BW. Treatments were done for 30 days by oral administration. Rats were sacrificed on Day 31 and the spleens were fixed in 10\% BNF. Spleens were made into histological specimen stained with Haematoxylin-Eosin then examined. Histological parameter analysis included the measurement of total body weight, spleen to body weight ratio, and spleen histology which consisted of surface area and diameter of the white pulp measurement and also the germinal center surface area measurement. Data obtained then analyzed using one way Analysis of variance and Duncan's. Statistical analysis on the surface area and diameter of the white pulp and also the surface area of the germinal center showed that there is a significant difference between the control group and all treatment groups $(\mathrm{P}>0.05)$. However, there was no significant difference found among treatment groups. In the case of total body weight, there was no statistical difference between treatment groups and control groups. Based on the results, papaya leaf ethanolic extract is able to increase the square measure and diameter of the white pulp as well as the square measure of the germinal center. Therefore, papaya leaf ethanolic extract is a potential natural immunomodulator.
\end{abstract}

Keywords: immunomodulator; calina papaya leaf extract; spleen; white pulp; germinal center

\begin{abstract}
ABSTRAK
Tanaman pepaya varietas calina (Carica papaya L. Var. calina) merupakan salah satu jenis tanaman pepaya yang banyak dibudidayakan di Indonesia. Tanaman ini memiliki kandungan senyawa aktif yang dapat berperan dalam meningkatkan kerja imun seperti flavonoid, polifenol, tanin dan saponin. Penelitian ini bertujuan untuk mengetahui aktivitas ekstrak etanol daun pepaya varietas calina sebagai imunomodulator alami terhadap struktur jaringan limpa tikus putih galur wistar (Rattus norvegicus Berkenhout, 1769). Penelitian menggunakan 24 ekor tikus wistar yang dibagi ke dalam empat perlakuan pemberian ekstrak yaitu kontrol (dosis 0 mg/kg BB), P1 (dosis 100 mg/kg BB), P2 (dosis 200 mg/kg BB), dan dosis P3 (300 mg/kg BB) selama 30 hari per oral. Parameter yang diamati meliputi bobot badan, rasio bobot limpa dan histologi limpa yang terdiri dari luas dan diameter pulpa putih serta luas germinal center. Tikus dikorbankan nyawanya pada hari ke-31, kemudian organ limpa diambil dan difiksasi dengan neutral buffer formaline 10\%. Limpa dibuat sediaan histologis dengan menggunakan blok parafin
\end{abstract}


dan pewarnaan hematoxylin-eosin. Data dianalisis dengan menggunakan sidik ragam satu arah kemudian dilanjutkan uji jarak berganda Duncan untuk mengetahui tingkat signifikansi antar perlakuan. Hasil penelitian menunjukkan bahwa seluruh perlakuan memberikan pengaruh yang signifikan $(\mathrm{P}<0,05)$, dalam hal menambah diameter dan memperluas pulpa putih serta memperluas germinal center pada limpa dibandingkan dengan kontrol. Bobot badan dan rasio organ limpa tidak menunjukan perbedaan secara siginifikan antar perlakuan $(\mathrm{P}>0,05)$. Simpulan penelitian adalah ekstrak etanol daun pepaya varietas calina memiliki potensi sebagai agen imunomodulator alami.

Kata-kata kunci: imunomodulator; ekstrak daun pepaya calina; limpa; pulpa putih; germinal center

\section{PENDAHULUAN}

Indonesia merupakan negara dengan tingkat kesehatan yang rendah. Berdasarkan data Riskesda (2018), prevalensi penyakit menular seperti tuberculosis/TB nasional $(0,4 \%)$, malaria $(0,4 \%)$, diare $(12,3 \%)$, dan pneumonia $(2 \%)$. Selain itu Indonesia masih memiliki tantangan dengan adanya kasus Human Immunodeficiency Virus/HIV yang pada tahun 2015 berjumlah 30.935 kasus dan meningkat menjadi 48.000 kasus pada tahun 2017 (Kemenkes RI, 2018). Melemahnya sistem imun menjadi salah satu faktor utama berbagai penyakit menular tersebut dapat dengan mudah masuk dan menyerang tubuh.

Sistem imun merupakan mekanisme tubuh untuk melindungi diri dari berbagai bahan asing berbahaya. Pada saat terjadi infeksi virus, maka sel penjamu menghasilkan interferon. Interferon (IFN) alfa/á dan betha/â, mencegah transkripsi dan translasi materi genetik virus, sedangkan interferon gamma/ã akan mengaktifkan makrofag dan Sel natural killer/ NK (Rosniza et al., 2017). Sel NK membunuh sel yang terinfeksi virus, sedangkan sel makrofag dan sel fagosit memakan virus dan juga menghasilkan IFN. Senyawa CD8+ menghancurkan peptida virus dan merusak sel yang terinfeksi, sedangkan $\mathrm{CD} 4+$ dapat mengaktifkan makrofag dan membentuk antibodi dan sel T sitotoksik (Baratawidjaja dan Rengganis, 2012). Menurut Sherwood (2016) salah satu sistem limfoid terbesar yang melakukan fungsi imun adalah limpa.

Limpa merupakan organ limfoid terbesar yang memiliki peran penting dalam sistem kekebalan tubuh. Limpa juga berperan dalam filtrasi eritrosit, pembersihan sel-sel eritosit yang tua dan rusak, serta reservoir platelet darah. Berdasarkan hal tersebut, limpa merupakan organ penting yang berperan pada pertahanan antigen dalam darah dan hematopoiesis individu (Brendolan et al., 2007; Hanadhita et al., 2018). Pada limpa terdapat pulpa putih yang merupakan kumpulan nodus limfatikus. Pulpa putih berfungsi sebagai tempat produksi antibodi dan pematangan dari limfosit $\mathrm{T}$ dan $\mathrm{B}$ serta makrofag (Mescher, 2012). Sel-sel limfosit yang berperan dalam imunitas spesifik, berkumpul dan berproliferasi dalam germinal center. Beberapa parameter untuk mengetahui adanya peningkatan aktivitas sistem imun ditandai dengan perubahan diameter pulpa putih dan germinal center (Rousdy et al., 2017). Terdapat beberapa senyawa yang dapat meningkatkan aktivitas sistem imun (imunomodulator) dan berperan dalam meningkatkan daya tahan tubuh.

Imunomodulator yang dikonsumsi dan diproduksi dalam industri kesehatan masih memiliki beberapa kendala. Salah satu kendala utama adalah harga yang mahal, karena dalam bentuk obat paten dan mayoritas diimpor dari luar negeri (Rahman et al., 2016). Beberapa obat paten yang berperan sebagai imunomodulator sering ditemukan di dalam tanaman herbal. Indonesia merupakan negara dengan biodiversitas tinggi dan memiliki banyak tanaman herbal yang berpotensi sebagai imunomodulator alami. Salah satu tanaman tradisional yang digunakan sebagai obat herbal alami adalah daun pepaya.

Tanaman pepaya saat ini banyak dimanfaatkan sebagai obat tradisional. Salah satu tanaman papaya yang dikembangan di Indonesia adalah pepaya varietas calina (Carica papaya L. Var. calina). Varietas ini memiliki keunggulan dengan batang-batang relatif pendek $(1 \mathrm{~m})$ dibanding dengan jenis pepaya lainnya dan sudah dapat dipanen setelah usia enam bulan (Hadi et al., 2018). Berdasarkan analisis fitokimia daun pepaya memiliki senyawa metabolik sekunder yang bermanfaat bagi tubuh. Beberapa kandungan pada daun pepaya sepeti tanin, saponin, alkaloid, flavonoid, triterpenoid (A'yun dan Layli, 2015). Komponen fenolik seperti flavonoid dan polifenol dapat meningkatkan sistem imun dengan cara meningkatkan Interleukin-12 (IL-12) dan 
proliferasi limfosit (Rauf et al., 2016). Senyawa IL-12 merangsang produksi IFN- $\gamma$ oleh sel NK, sementara IFN- $\gamma$ berfungsi untuk mengaktifkan makrofag (Jingga et al., 2019).

Makiyah dan Wardhani (2017) serta Trinaya et al. (2019) menyatakan senyawa aktif seperti flavonoid dapat meningkatkan proliferasi sel limfosit yang ditandai dengan peningkatan luas diameter pulpa putih dan luas germinal center pada limpa. Berdasarkan latar belakang tersebut, penelitian ini bertujuan untuk mengetahui aktivitas imunomodulator ekstrak etanol daun pepaya varietas calina terhadap limpa tikus wistar.

\section{METODE PENELITIAN}

\section{Kaji Etik/Ethical Clearance}

Penelitian ini telah dilakukan sesuai dengan prosedur baku yang telah mendapatkan keterangan kelayakan oleh Komite Etik Penelitian Universitas Ahmad Dahlan dengan nomor sertifikat 012002007.

\section{Pembuatan Ekstrak Etanol Daun Pepaya Calina}

Daun pepaya pada penelitian ini diperoleh dari perkebunan buah di Dayakan, Sanggrahan, Purwomartani, Kecamatan Kalasan, Sleman, Daerah Istimewa Yogyakarta. Determinasi tanaman dilakukan oleh Laboratorium Biologi, Universitas Ahmad Dahlan dengan nama ilmiah Carica papaya L. Var. calina dan telah memperoleh nomor surat 149/Lab.Bio/B/X/ 2019.

Daun pepaya sebanyak $11 \mathrm{~kg}$ dipisahkan antara tulang dan helaian daunnya untuk kemudian dicuci, dikeringkan dengan cara diangin-anginkan, diblender dan diayak hingga diperoleh serbuk simplisia dengan bobot $2 \mathrm{~kg}$. Serbuk simplisia diekstraksi dengan metode maserasi dengan pelarut etanol 96\%. Maserasi dilakukan selama tiga hari dengan penggojokan dua kali sehari yaitu pada pagi dan sore hari. Hasil maserasi dipisahkan dengan corong pisah dan kertas saring. Filtrat yang didapatkan diuapkan menggunakan rotary evaporator pada suhu $60^{\circ} \mathrm{C}$ selanjutnya dipanaskan, dikentalkan dengan penangas air/waterbath pada suhu $80^{\circ} \mathrm{C}$ hingga ekstrak menjadi kental. Hasil ekstrasi didapatkan 83,7 g ekstrak kental daun pepaya.
Pemeliharaan dan Perlakuan Hewan Coba

Penelitian ini menggunakan 24 ekor tikus wistar umur 3-4 bulan dengan bobot $200 \mathrm{~g}$. Tikus dibagi menjadi empat perlakuan dengan enam ekor ulangan. Perlakuan terdiri dari Kontrol (dosis 0 mg/kg BB), P1 (dosis 100 mg/ $\mathrm{kg} \mathrm{BB}$ ), P2 (dosis $200 \mathrm{mg} / \mathrm{kg} \mathrm{BB}$ ), dan dosis P3 (300 mg/kg BB) yang dilarutkan dalam $1 \mathrm{~mL}$ aquadest (Setiawan dan Yuniarto, 2015). Tikustikus wistar diberi kesempatan melakukan aklimatisasi selama tujuh hari sebelum perlakuan.

Pemberian pakan dan air minum pada tikus dilakukan secara ad libitum. Tikus selanjutnya diberikan perlakuan selama 30 hari secara oral dengan menggunakan sonde lambung ukuran $3 \mathrm{~mL}$. Bobot badan tikus ditimbang setiap satu minggu sekali. Pada hari ke-31 tikus dibius kemudian dikorbankan nyawanya dengan cara dislokasi leher dan dilakukan pengambilan organ limpa untuk pembuatan preparat histologi.

\section{Pembuatan Preparat Histologi}

Organ limpa yang telah diambil, dicuci dengan menggunakan $\mathrm{NaCl}$ 0,9\% untuk menghilangkan kotoran dan darah. Organ limpa ditimbang menggunakan timbangan digital untuk mengetahui bobot organ limpa (Setiawan et al., 2018). Dihitung rasio organ limpa dengan membagi bobot limpa dengan bobot badan akhir tikus. Selanjutnya organ difiksasi dalam larutan Neutral Buffer Formaline 10\% selama 24 jam untuk pembuatan preparat histologi. Pembuatan preparat histologi menggunakan metode blok paraffin dengan pewarnaan hematoxylin-eosin.

\section{Pengamatan Preparat Histologi}

Pengamatan preparat dilakukan dengan menggunakan mikroskop cahaya dan optilab. Preparat diamati pada lima bidang pengamatan dengan perbesaran 40 kali dan 100 kali, kemudian diukur diameter dan luas pulpa putih serta luas germinal center pada limpa dengan menggunakan aplikasi Image Raster.

\section{Analisis Data}

Seluruh parameter penelitian diuji homogenitas dan normalitas dan dilanjutkan dengan uji sidik ragam satu arah. Perbedaan yang memiliki nilai signifikasi $\mathrm{P}<0,05$ antar perlakuan, kemudian dilanjutkan dengan uji jarak berganda Duncan untuk mengetahui tingkat signifikansi antar perlakuan. 


\section{HASIL DAN PEMBAHASAN}

\section{Bobot Badan}

Pengamatan bobot badan bertujuan untuk memantau perubahan bobot badan pada tikus yang disebabkan oleh pengaruh pemberian ekstrak etanol daun pepaya, selain itu penimbangan bobot badan juga digunakan untuk memantau kesehatan hewan coba.

Berdasarkan hasil uji sidik ragam menunjukkan tidak terdapat pengaruh yang signifikan $(\mathrm{P}>0,05)$ antar kelompok perlakuan ekstrak etanol daun pepaya dibanding dengan kontrol pada pengamatan bobot badan tikus wistar dan rasio bobot organ limpa. Bobot badan tikus wistar menunjukkan adanya peningkatan bobot badan secara bertahap, namun terdapat penurunan bobot badan pada dosis $300 \mathrm{mg} / \mathrm{kg}$ BB yang terjadi pada minggu ke-4. Halim et al. (2011) pada studi toksisitas akut daun pepaya menunjukan dosis $2000 \mathrm{mg} / \mathrm{kg}$ BB per oral tidak mengakibatkan adanya perubahan bobot badan, perubahan morfologi pada organ, maupun efek toksik yang berakibat pada kematian hewan coba tikus. Penelitian Tarkang et al. (2012) juga menunjukan bahwa uji toksisitas sub kronis dan

Tabel 1. Data bobot badan tikus pada tiap perlakuan ekstrak etanol daun pepaya (Carica papaya. L. var. calina) pada minggu ke-0 sampai ke-4

\begin{tabular}{lcccr}
\hline \multirow{2}{*}{ Minggu } & \multicolumn{4}{c}{ Bobot Badan (g) } \\
\cline { 2 - 5 } & Kontrol & P1 & P2 & P3 \\
\hline 0 & $256,17 \pm 27,82^{\mathrm{a}}$ & $244,83 \pm 47,38^{\mathrm{a}}$ & $256,67 \pm 27,74^{\mathrm{a}}$ & $256,67 \pm 35,91^{\mathrm{a}}$ \\
1 & $258,5 \pm 32,05^{\mathrm{a}}$ & $244,33 \pm 37,45^{\mathrm{a}}$ & $256,17 \pm 29^{\mathrm{a}}$ & $265,5 \pm 32,36^{\mathrm{a}}$ \\
2 & $272,67 \pm 34,26^{\mathrm{a}}$ & $268 \pm 36,20^{\mathrm{a}}$ & $277,33 \pm 27,86^{\mathrm{a}}$ & $291,83 \pm 31,26^{\mathrm{a}}$ \\
3 & $278,83 \pm 22,60^{\mathrm{a}}$ & $287 \pm 36,85^{\mathrm{a}}$ & $297,83 \pm 29,73^{\mathrm{a}}$ & $291,22 \pm 31,80^{\mathrm{a}}$ \\
4 & $294,83 \pm 24,89^{\mathrm{a}}$ & $293,5 \pm 41,45^{\mathrm{a}}$ & $302,67 \pm 29,65^{\mathrm{a}}$ & $287,17 \pm 28,94^{\mathrm{a}}$ \\
\hline
\end{tabular}

Keterangan: Kontrol (Ekstrak etanol daun pepaya $0 \mathrm{mg} / \mathrm{kg} \mathrm{BB}$ ), P1(Eksrtak etanol daun pepaya $100 \mathrm{mg} /$ $\mathrm{kg} \mathrm{BB}$ ), P2(Ekstrak etanol daun pepaya $200 \mathrm{mg} / \mathrm{kg} \mathrm{BB}$ ), P3 (Ekstrak etanol daun pepaya 300 $\mathrm{mg} / \mathrm{kg} \mathrm{BB})$. Rataan \pm Simpangan baku. ${ }^{a}$ Notasi angka yang diikuti huruf yang sama di dalam kolom menunjukkan tidak terdapat perbedaan secara signifikan $(\mathrm{P}>0,05)$.

Tabel 2. Bobot organ limpa tikus pada tiap kelompok setelah pemberian ekstrak etanol daun pepaya (Carica papaya. L.var. calina)

\begin{tabular}{lcc}
\hline Perlakuan & Bobot limpa (g) & $\begin{array}{c}\text { Rasio bobot limpa/ } \\
\text { bobot badan(\%) }\end{array}$ \\
\hline Kontrol & $1,06 \pm 0,10^{\mathrm{a}}$ & $0,39 \pm 0,05^{\mathrm{a}}$ \\
P1 & $1,09 \pm 0,10^{\mathrm{a}}$ & $0,40 \pm 0,05^{\mathrm{a}}$ \\
P2 & $1,21 \pm 0,24^{\mathrm{a}}$ & $0,39 \pm 0,03^{\mathrm{a}}$ \\
P3 & $1,02 \pm 0,18^{\mathrm{a}}$ & $0,37 \pm 0,07^{\mathrm{a}}$ \\
\hline
\end{tabular}

Keterangan: Kontrol (Ekstrak etanol daun pepaya $0 \mathrm{mg} / \mathrm{kg}$ BB), P1(Ekstrak etanol daun pepaya $100 \mathrm{mg} / \mathrm{kg} \mathrm{BB}$ ), P2(Ekstrak etanol daun pepaya $200 \mathrm{mg} / \mathrm{kg} \mathrm{BB}$ ), P3 (Ekstrak etanol daun pepaya 300 $\mathrm{mg} / \mathrm{kg}$ BB). Rataan \pm Simpangan baku. ${ }^{a}$ Notasi angka yang diikuti huruf yang sama di dalam kolom menunjukkan tidak terdapat perbedaan secara signifikan $(\mathrm{P}>0,05)$. sub akut pada ekstrak aqueous dan etanol daun pepaya tidak menunjukan efek toksik pada parameter hematologi, biokimia dan histopatologi pada tikus wistar. Penurunan bobot badan ini disebabkan oleh nafsu makan tikus yang berbeda-beda setiap hari selama penelitian, hal ini ditunjukkan dengan adanya sisa pakan di setiap kandang selama pemeliharaan. Daun pepaya juga mengandung beberapa senyawa fitokimia, salah satunya tanin. Senyawa tanin merupakan senyawa yang bersifat mudah berikatan dengan protein dan menyebabkan protein di permukaan usus mengendap yang menyebabkan penyerapan sari-sari pakan pada usus menjadi berkurang (Ardiansyah et al., 2018).

Bobot limpa dan rasio limpa dengan bobot badan menunjukan tidak terdapat perbedaan secara signifikan $(\mathrm{P}>0,05)$. Organ limpa pada seluruh perlakuan memiki karakteristik sehat dengan warna merah tua, permukaan licin dan rata serta bertekstur kenyal. Adapun ciri limpa 
yang mengalami hiperplasia atau inflamasi secara makroskopik ditandai dengan perubahan konsistensi, limpa menjadi lebih lunak, selain itu memiliki warna coklat tua hampir kehitaman, dengan tepi yang cenderung tumpul atau membulat (Goni et al., 2017). Pengamatan makroskopis organ limpa pada seluruh perlakuan menunjukan bahwa ekstrak etanol daun pepaya tidak menunjukan efek toksik seperti hiperplasia dan inflamasi pada limpa, sehingga ekstrak ini tidak menimbulkan gejala toksisitas pada tikus.

\section{Histologi Limpa}

Pulpa putih limpa merupakan tempat pematangan dan penggandaan serta diferensiasi limfosit (Makiyah, 2014). Pada pulpa putih terdapat zona limfosit $\mathrm{B}$ dan limfosit $\mathrm{T}$ yang memungkinkan adanya respons imun spesifik. Penelitian menunjukan bahwa diameter dan luas pulpa putih limpa berbeda secara signifikan $(\mathrm{P}<0,05)$ dibandingkan dengan kontrol. Pada perlakuan dosis $100 \mathrm{mg} / \mathrm{kg} \mathrm{BB}$, menunjukan bahwa diameternya lebih panjang dan pulpa putih lebih luas dibandingkan dengan kontrol. Perbesaran diameter serta luas pulpa putih memperlihatkan peningkatan aktivitas sistem imun, karena terjadi proliferasi sel-sel pada pulpa putih yang diakibatkan adanya antigen yang masuk serta pengaruh dari pemberian ekstrak etanol daun pepaya calina (Makiyah et al., 2017).

Proliferasi limfosit terjadi karena peningkatan produksi limfoblast yang menjadi limfosit dan secara makroskopis dapat terlihat dari perbesaran organ limfoid (Ganong, 2010). Diduga ekstrak etanol daun pepaya calina memiliki beberapa senyawa metabolit sekunder yang mampu merangsang peningkatan aktivitas sistem imun dan dapat menyebabkan proliferasi sel limfosit. Senyawa aktif yang mempunyai bioaktivitas sebagai agen imunomodulator di antaranya golongan senyawa polisakarida, terpenoid, alkaloid, dan polifenol.

Senyawa flavonoid pada ekstrak etanol daun pepaya memiliki kemampuan meningkatkan produksi serta aktivasi interleukin 2 (IL2) yang terlibat aktif dalam aktivasi dan proliferasi sel limfosit atau limfosit $\mathrm{T}$ (Dewi et al., 2013; Meliana, 2016). IL-2 merupakan salah satu sitokin yang berfungsi untuk mengatur respons imun, seperti untuk mitogen bagi sel $\mathrm{T}$, secara potensial meningkatan proliferasi dan aktivasi sel T, sel B, dan sel NK. Selain itu, IL2 juga berperan dalam memperbaiki pembentukan antigen dan meningkatkan produksi sitokin lainnya (Sukmayadi et al., 2014). Diduga bahwa flavonoid pada ekstrak daun pepaya calina memicu produksi dan aktivasi IL-2. Aktivitas ini mengakibatkan proliferasi sel limfosit sehingga meningkatkan luas dan diameter pulpa putih.

Secara tidak langsung, diduga ekstrak etanol daun pepaya juga dapat meningkatkan sistem imun dengan berperan sebagai senyawa antioksidan, antikanker, maupun antibakteri (Suparman dan Saptarini, 2019). Flavonoid dan alkaloid pada ekstrak daun pepaya bekerja dalam menghambat pertumbuhan bakteri patogen dengan merusak protoplasma, sehingga dapat menembus dinding sel bakteri dan mampu mengendapkan protein sel bakteri (Tuntun, 2016).

Senyawa karotenoid dan glukosinolat daun pepaya juga memiliki aktivitas antioksidan yang memengaruhi sistem pertahanan seluler tubuh, terhadap penghambatan pengikatan radikal bebas (Sandiutami et al., 2016). Aktivitas ini

Tabel 3. Rerata luas, diameter pulpa putih dan luas germinal center limpa tikus pada setiap kelompok perlakuan

\begin{tabular}{lccc}
\hline Perlakuan & $\begin{array}{c}\text { Luas Pulpa Putih } \\
\text { Limpa }\left(\mu \mathrm{m}^{2}\right)\end{array}$ & $\begin{array}{c}\text { Diameter Pulpa Putih } \\
\text { Limpa }(\mu \mathrm{m})\end{array}$ & $\begin{array}{c}\text { Luas germinal } \\
\text { center }\left(\mu \mathrm{m}^{2}\right)\end{array}$ \\
\hline Kontrol & $176.772 \pm 104.604,90^{\mathrm{a}}$ & $454,68 \pm 143,53^{\mathrm{a}}$ & $233,27 \pm 91,23^{\mathrm{a}}$ \\
P1 & $281.956,10 \pm 135.234,50^{\mathrm{b}}$ & $571,61 \pm 148,01^{\mathrm{b}}$ & $291,91 \pm 85,51^{\mathrm{b}}$ \\
P2 & $392.510,90 \pm 126.144,90^{\text {cd }}$ & $668,57 \pm 115,47^{\text {cd }}$ & $337,86 \pm 91,20^{\mathrm{b}}$ \\
P3 & $345.847,40 \pm 125.289,90^{\text {cd }}$ & $656,18 \pm 125,12^{\text {cd }}$ & $318,64 \pm 76,68^{\mathrm{b}}$ \\
\hline
\end{tabular}

Keterangan: Kontrol (Ekstrak etanol daun pepaya $0 \mathrm{mg} / \mathrm{kg} \mathrm{BB}), \mathrm{P} 1($ Ekstrak etanol daun pepaya $100 \mathrm{mg} /$ $\mathrm{kg} \mathrm{BB}$ ), P2(Ekstrak etanol daun pepaya $200 \mathrm{mg} / \mathrm{kg} \mathrm{BB})$, P3(Ekstrak etanol daun pepaya 300 $\mathrm{mg} / \mathrm{kg} \mathrm{BB})$. Rataan \pm Simpaangan baku. ${ }^{\text {a-d }}$ Perbedaan notasi pada angka yang diikuti huruf berbeda dalam kolom yang sama menunjukkan perbedaan secara signifikan $(\mathrm{P}<0,05)$. 
dapat mengurangi potensi bahaya mitogenik maupun karsinogenik suatu zat yang dapat menimbulkan penyakit degeneratif seperti kanker (Huang et al., 2009; Suparman dan Saptarini, 2019).

Hasil uji statistika terhadap luas germinal center limpa, menunjukan adanya perbedaan yang signifikan antar perlakuan $(\mathrm{P}<0,05)$. Pada perlakuan dosis $100 \mathrm{mg} / \mathrm{kg} \mathrm{BB}$, menunjukan adanya perbedaan yang signifikan, yaitu memiliki luas germinal center lebih luas dibandingkan dengan kontrol. Analisis data tersebut menunjukkan bahwa senyawa metabolit sekunder ekstrak etanol daun pepaya memiliki pengaruh terhadap peningkatan luas germinal center.

Flavonoid memiliki kemampuan sebagai imunomodulator dengan cara merangsang produksi sitokin pada sel T helper tipe 1 (Th 1), yang berperan dalam pengaturan sistem imun (Yogiraj et al., 2014). Flavonoid memiliki kemampuan dalam meningkatkan produksi IL2 yang terlibat aktif dalam aktivasi dan proliferasi sel limfosit (Dewi et al., 2013; Meliana, 2016). Keberadaan flavonoid dapat meningkatkan sekresi IL-12 oleh AntigenPresenting Cells (APCs) untuk selanjutnya menginduksi sel T (Th-0). Sel Th-0, mengalami proliferasi dan diferensiasi menjadi sel Th-1 dan Th-2 (Carmelita, 2016).

Senyawa flavonoid pada ekstrak etanol daun pepaya menginduksi APC untuk mensekresikan beberapa sitokin lainnya seperti IL-1. Menurut Barathawidjaja dan Rengganis (2012), IL-1 kemudian menginduksi Th-1 untuk mensekresikan IL-2 dan IFN- ã. Kedua sitokin
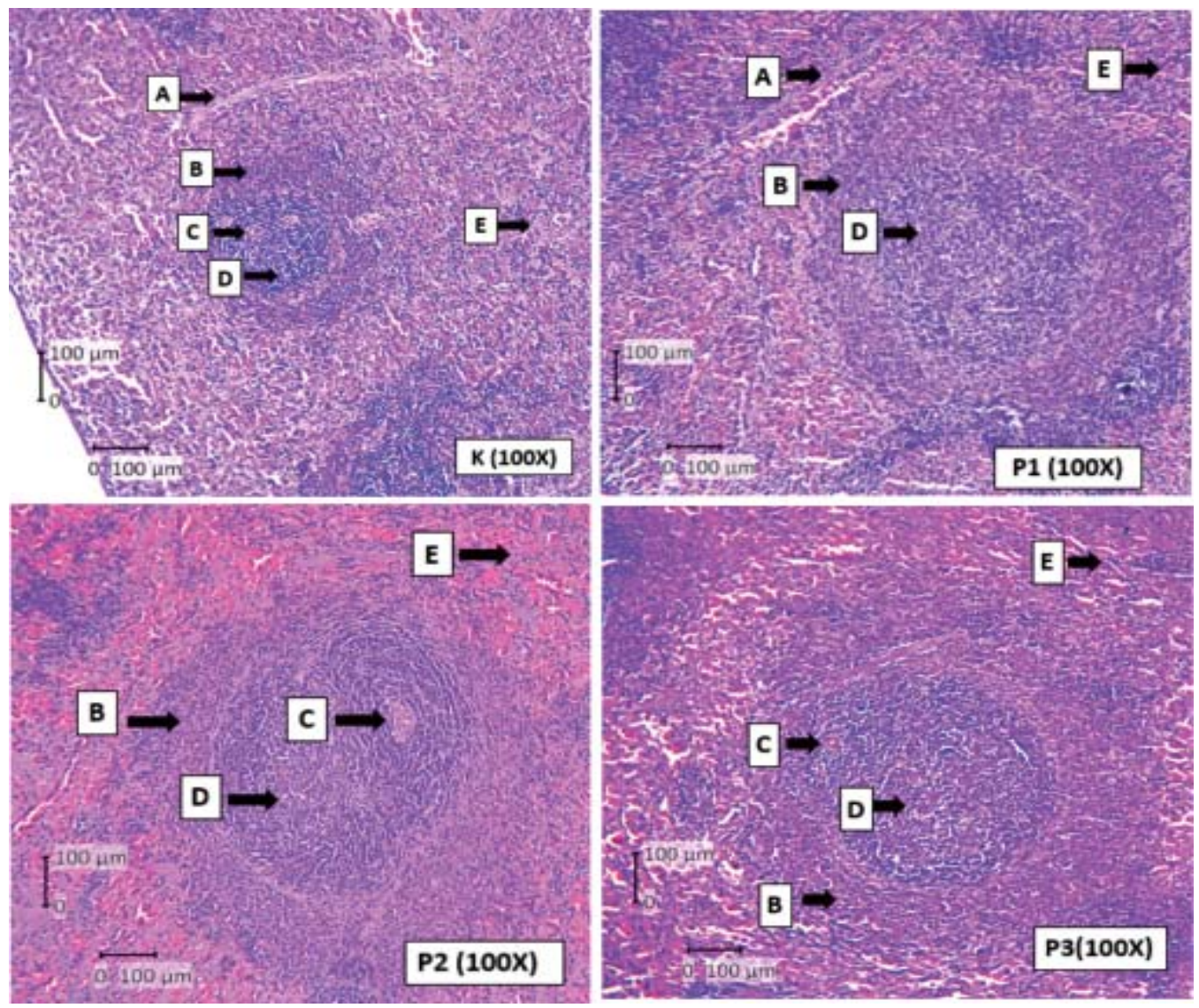

Gambar 1. Histologi organ limpa setelah pemberian ekstrak etanol daun pepaya. Keterangan: Kontrol (Ekstrak etanol daun pepaya $0 \mathrm{mg} / \mathrm{kg} \mathrm{BB}$ ), P1(Ekstrak etanol daun pepaya 100 $\mathrm{mg} / \mathrm{kg} \mathrm{BB}$ ), P2 (Ekstrak etanol daun pepaya $200 \mathrm{mg} / \mathrm{kg} \mathrm{BB}$ ), P3 (Ekstrak etanol daun pepaya $300 \mathrm{mg} / \mathrm{kg} \mathrm{BB}$ ). (Bagian pada histologi limpa ditunjuk huruf A (trabekula); B (pulpa putih); C (arteri centralis); D (germinal center); E (pulpa merah). Terlihat pada perlakuan memiliki luas pulpa dan germinal center yang lebih besar dibandingkan dengan kontrol (Pewarnaan Hematoxilyn-Eosin perbesaran 100 kali). 
ini kemudian menginduksi Th-2 untuk mensekresikan sitokin lainnya seperti IL-4, IL5, IL-6, IL 13, dan IL-10 yang mengaktivasi sel limfosit B berproliferasi dan berdiferensiasi menjadi sel plasma (Sudiana, 2011). Peningkatan aktivitas proliferasi sel limfosit kemudian terjadi yang ditandai dengan adanya perubahan secara mikroskopis berupa peningkatkan luas germinal center dan pulpa putih. Kedua situs ini merupakan lokasi diferensiasi, proliferasi, dan berkumpulnya selsel limfosit (Carmelita, 2016).

Hefni et al. (2013) menjelaskan bahwa daun kelor selain mengandung senyawa flavonoid, terdapat senyawa saponin dan ion kalsium (Ca) yang mampu menginduksi peningkatan ekspresi IL-2 yang berperan dalam proliferasi sel Th. Ekstrak etanol daun pepaya diduga memiliki senyawa saponin dan ion $\mathrm{Ca}$ yang memiliki aktivitas sama dengan daun kelor (Mahatriny et al., 2014). Senyawa saponin dan ion $\mathrm{Ca}$ secara molekuler menginduksi protooncogene yang berperan dalam pengaturan produksi dan proliferasi sel. Keterlibatan protooncogene ini mengatur tranduksi sinyal mitogen melalui aktivasi IL-2 yang disebut juga sel T limfosit growth factor (Chen et al., 2003).

Kandungan mineral pada ekstrak daun pepaya seperti kalsium memiliki peran penting dalam proses pengaktifan limfosit-T. Ion kalsium (Ca) berperan pada protein kinase terutama dalam proses tranduski sinyal yang diperlukan saat proses proliferasi sel limfosit T (Litchman et al., 1983; Chen et al., 2003). Pemberian ekstrak etanol daun pepaya selama 30 hari menunjukkan adanya peningkatan aktivitas imun, ditandai dengan terjadinya peningkatakan luas germinal center dan pulpa putih limpa. Peningkatan luas pulpa putih terjadi akibat adanya proliferasi limfosit, dan diferensiasi limfosit terjadi pada germinal center. Berdasarkan hal tesebut ekstrak etanol daun pepaya memiliki aktivitas imunomodulator yang dapat meningkatkan sistem imun ditandai dengan perluasan germinal center dan pulpa putih pada limpa.

\section{SIMPULAN}

Simpulan penelitian adalah ekstrak etanol daun pepaya varietas calina mampu meningkatan diameter dan luas pulpa putih serta luas germinal center dan memiliki potensi sebagai agen imunomodulator alami.

\section{SARAN}

Untuk penelitian selanjutnya perlu dilakukan analisis Gas Cromatography and Mass Spectroscopy (GCMS) untuk mengetahui kadar senyawa metabolit yang bermanfaat sebagai imunomodulator. Diperlukan juga pengujian untuk mengatahui kadar limfosit serta IL-2 yang berperan dalam peningkatan aktivitas imun pada organ limpa tikus wistar setelah pemberian ekstrak etanol daun pepaya calina.

\section{UCAPAN TERIMA KASIH}

Penelitian ini didanai oleh Lembaga Penelitian dan Pengabdian Masyarakat (LPPM) Universitas Ahmad Dahlan 2020. Penulis menyatakan tidak ada konflik kepentingan dengan pihak-pihak yang terkait dalam penelitian ini.

\section{DAFTAR PUSTAKA}

Ardiansyah SA, Hidayat DS, Simbolon SN. 2018. Uji aktivitas antiobesitas etanol daun malaka (Phyllanthus emblica L.) terhadap tikus jantan galur wistar. $J$ of Pharmaceutical Science and Tehnology 1(1): 18-29.

A'yun Q, Laily AN. 2015. Analisis Fitokomia Daun Pepaya (Carica papaya. L). di Balai Penelitian Tanaman Aneka Kacang dan Umbi, Kendalpayak, Malang. Dalam Seminar Nasional Konservasi dan Pemanfaatan Sumber Daya Alam. Januari 2015. Malang. Universitas Islam Negeri Maulana Malik Ibrahim. Hlm. 134-137.

Barathawidjaja KG, Rengganis I. 2012. Imunologi Dasar. Jakarta. Badan Penerbit Fakultas Kedokteran. Universitas Indonesia. Hlm. 211-220.

Brendolan A, Rosado MM, Carsetti R. Selleri L, Dear TN. 2007. Development and Function of the Mamalian Spleen. Bio Essays 29: 166-177.

Carmelita AB. 2016. Pengaruh Pemberian Ekstrak Etanol Umbi Bawang Dayak (Eleutherine palmifolia (L) Merr) Secara Oral pada Mencit Balb-C Terhadap Pencegahan Penurunan Diameter Germinal 
Center pada Kelenjar Getah Bening Serta Kadar IgM Serum. J Biosains Pascasarjana 18(1). file:///C:/Users/ACER/AppData/Local/ Temp/2987-7758-2-PB.pdf

Chen HL, Li DF, Chang B, Gong LM, Piao XS, Yi GF, Zhang JS. 2003. Effects of Lentinan on Broiler Splenocyte Proliferation, Interleukin-2, Production, and Signal Tranduction. J Poultry Science 82: 760 766.

Dewi LK, Widyanarti S, Rifai M. 2013. Pengaruh Pemberian Ekstrak Etanol Annona muricata Linn Terhadap Peningkatan Jumlah Sel CD4+ dan CD8+ pada Timus Mencit (Mus musculus). Biotropika 2(5): 269-272. https://biotropika.ub.ac.id/ index.php/biotropika/article/view/101

Ganong WF. 2010. Ganong's Review of Medical Physiology Edisi 23. United States. MC GrawHill. Hlm. 521-527.

Goni LR, Wongkar D, Wangko SG. 2017. Gambaran Mikroskopik dan Mikroskopik Limpa pada Hewan Coba Postmortem. J eBio-Medik 5(1): 1-6.

Hadi SN, Herliana O,Widiyawati I. 2018. Penerepan Teknologi Budidaya Pepaya Calina Menggunakan Bibit Unggul dan Sistem Pertanaman Intensif di Lahan Tegalan Desa Patemon, Purbalingga, Jawan Tengah. Logista-Jurnal Ilmiah Pengabdian kepada Masyarakat 2(2): 1-8.

Halim SZ, Abdullah NR, Afzan A, Rashid BAA, Jantan I, Ismail Z. 2011. Acute Toxicity Study of Carica Papaya Leaf Extract in Sparague Dawley Rats. J Medicinal Plants Research 14(20): 1867-1872.

Hanadhita D, Prawira YA, Rahma A, Setyaningtijas SA, Agungpriono S. 2018. Morfometri Limpa Berkaitan dengan Produksi Radikal Bebas dan Antioksidan pada Kelelawar Pemakan Buah Codot Kawar (Cunopterus brachyoni). Jurnal Veteriner 19(1): 62-70.

Hefni M, Rifa'I M, Widodo. 2013. Aktivitas Ekstrak Daun Kelor terhadap Respon Imun Humoral pada Mencit yang Diinfeksi Salmonella typi. Jurnal Veteriner 14(4): 519-526.

Huang WY, Cai YZ, Zhang Y. 2009. Natural Phenolics Compouns from Medical Herbs and Dietary Plant: Potential Use For Cancer
Prevention. Nutrition and Cancer 62(1): $1-22$.

Jingga ME, Setiawan H, Nuriliani A, Saragih TH. 2019. Biosupplementation of Ethanolic Extract of Cashew Leaf (Anacardium occidentale) to Improve Weight Gain and Immunity of Jawa Super Chicken. Acta Veterinaria Indonesiana 7(2): 57-65.

Kementrian Kesehatan RI. 2019. Profil Kesehatan Indonesia 2018. Jakarta. Kementerian Kesehatan Republik Indonesia.

Lichtman AH, Segel GB, Lichtman MA. 1983. The Role of Calcium in Lymphocyte Proliferation (An Interpretive Review). J The America Society of Hematology 61(3): 413422.

Mahatriny NN, Payani NPS, Oka IBM, Astuti KW. 2014. Skrining Fitokimia Ekstrak Etanol Daun Pepaya (Carica papaya L) yang Diperoleh dari Daerah Ubud Kabupaten Gianyar Bali. J Farmasi Udayana 3(1): 813.

Makiyah SN, Iszamriach R, Nofariyandi A. 2014. Paparan Sinar Ultraviolet C Meningkatkan Diameter Pulpa Alba Limpa dan Indeks Mitotik Epidermis Kulit Mencit. J Kedokteran Brawijaya 28 (1): 14-21.

Makiyah SNN, Wardhani UH. 2017. Potensi Ekstrak Etanol Buah Citrullus lanatus sebagai Agen Imunosupresi melalui Pengamatan Histologi Limpa Mencit BALB/ c. Majalah Kedokteean Bandung 49(4): 245251.

Meliana N. 2016. Pengaruh Pemberian Ekstrak Etanol Umbi Bawang Dayak (Eleuthrine palmifolia L) Secara Oral Pada Mencit BALB/c Terhadap Pencegahan Penurunan Jumlah NK Sel dan CD $8^{+}$. J Biosains Pascasarjana 18(1): 13-23.

Mescher AL. 2012. Histologi Dasar Junquiera Teks \& Atlas. Jakarta. Penerbit Buku Kedokteran EGC. Hlm. 221-239.

Rahman H, Aldi Y, Maryanti E. 2016. Aktivitas Imunomodulator dan Jumlah Sel Leukosit Dari Ekstrak Kulit Buah Naga Merah (Hylocereus lemairei) pada Mencit Putih Jantan. Jurnal F Higea 8(1): 44-58.

Rauf A, Haeria, Anas DD. 2016. Efek Imunomodulator Fraksi Daun Katuk (Sauropus androgynus L. MERR) Terhadap 
Aktivitas dan Kapasitas Fagositosis Makrofag Pada Mencit Jantan (Mus musculus). J Farmasi Universitas Islam Negeri Alauddin 4(1): 9-15.

Riskesda. 2018. Hasil Utama Riskesdas 2018. Jakarta. Badan Peneliti dan Pengembangan Kesehatan Kementerian Kesehatan RI 2018.

Rosnizar R, Maulida S, Eriani K, Suwarno. 2017. Potensi Ekstrak Daun Flamboyan (Delonix regia (Boj.Ex Hook.) Raf) Terhadap Peningkatan Aktivitas dan Kapasitas Makrofag. J Bioleuser 1(3): 104-115.

Rousdy DW, Rahmawati, Kurniatuhadi R, Kuniadi E. 2017. Mikroanatomi Limpa Tikus (Rattus norvegicus L.) Setelah Pemberian Asam Humat Dari Tanah Gambut Kalimantan. J Penelitian dan Pengembangan Borneo Akcaya 4(1): 57-62.

Sandiutami NMD, Desmiaty Y, Anbar A. 2016. Efek Antioksidan Ekstrak Etanol Biji Pepaya (Carica papaya L.) Terhadap Aktivitas Enzim Superoksida Dismutase dan Kadar Malondialdehid pada Mencit Stress Oksidatif Peradangan. J Ilmu Kefarmasian Indonesia 14(1): 26-32.

Setiawan H, Yunianto I. 2015. Aktivitas Antispermatogenik Ekstrak Etanol Daun Jambu Mete (Anacardium Occidentale L.) terhadap Mencit (Mus Musculus L.) sebagai Materi Pembelajaran Siswa SMA Kelas XI IPA untuk Mencapai KD 3.12 Kurikulum 2013. Jupemasi-Pbio 1(2): 212-218.

Setiawan H, Utami LB, Zulfikar M. 2018. Serbuk Daun Jambu Biji Memperbaiki Performans Pertumbuhan dan Morfologi Duodenum Ayam Jawa Super. Jurnal Veteriner 19(4): 554-567.

Sherwood L. 2016. Fisiologi Manusia Dari Sel ke Sistem. Jakarta. EGC. Hlm. 443-479.
Sudiana IK. 2011. Limfosit dalam Patobiologi Molekuler Kanker. Jakarta. Salemba Medika. Hlm. 77-83.

Sukmayadi AE, Sumiwi AS, Barliana MI, Aryanti AD. 2014. Aktivitas Imunomodulator Ekstrak Etanol Daun Tempuyung (Sonchus arvensis Lin.). Indonesian Journal of Pharmaceutial Sciene and Technology 1(2): 1-8.

Suparman A, Saptarini NM. 2019. Review Artikel: Formulasi Tablet Imunostimulan Ekstrak Daun Pepaya, Herba Meniran, dan Rimpang Kunyit. J Farmaka 17(2): 111117.

Tarkang PA, Agbor GA, Armelle TD, Yamthe TLR, David K, Ngadena SM. 2012. Acute and Chronic Toxicity Studies of the aqueous and ethanol leaf extracts of Carica papaya Linn in Wistar rats. J Nat Prod Plant Resour 2(5): 617-627.

Trinaya AAABA, Linawati NM, Wahyuniari AI, Ratnayanti ID, Arijana IN, Sugiritama IW, Wiryawan IS. 2019. Pengaruh Teh Kombinasi Bunga Euphorbia milli dan Propolis Tehadap Jumlah Nodulus Limfa Tikus dan Diameter Sentrum Germinativum pada Limpa Mencit yang Diinfeksi Mycobacteriu tuberculosis . E-Jurnal Medika 8(6): 1-8. https://ojs.unud.ac.id/ index.php/eum/article/view/50134/29866

Tuntun M. 2016. Uji Efektivitas Ekstrak Daun Pepaya (Carica papaya L.) Terhadap Pertumbuhan Bakteri Escheria coli dan Stapylococcus aureus. J Kesehatan 7(3): 497-502.

Yogiraj V, Goyal PK, Chauhan CS, Goyal A, Viass B. 2014. Carica papaya Linn: Ann Overview. J International of Herbal Medicine 2(5): 1-8. 